\title{
INSPIRO project - Educational intervention against non-adherence to inhalation therapy for Romanian asthma and COPD patients
}

Ruxandra Ulmeanu ${ }^{1,2}$, Alina Croitoru ${ }^{1,3, *}$, Floarea Mimi Nitu ${ }^{4}$, Florin Mihaltan ${ }^{1,3}$, Cristian Oancea ${ }^{5}$, Ramona Nedelcu ${ }^{1}$, Daniela Boldeanu ${ }^{6}$, Ruxandra Rajnoveanu ${ }^{7}$, Petronela Fildan ${ }^{8}$, INSPIRO team

${ }^{1} /$ nstitute of Pneumophysiology Marius Nasta, Bucharest, Romania

${ }^{2}$ Faculty of Medicine and Pharmacy, Oradea, Romania

${ }^{3}$ University of Medicine and Pharmacy Carol Davila, Bucharest, Romania

${ }^{4}$ University of Medicine and Pharmacy, Craiova, Romania

${ }^{5}$ University of Medicine and Pharmacy Victor Babes, Timisoara, Romania

${ }^{6}$ Pneumophtysiology Clinic Leon Daniello, Cluj Napoca, Romania

${ }^{7}$ University of Medicine and Pharmacy luliu Hatieganu, Cluj Napoca, Romania

${ }^{8}$ Faculty of Medicine - Ovidius University, Constanta, Romania

Abstract

English:

Background: In the management of chronic respiratory diseases such as asthma and chronic obstructive pulmonary disease (COPD), adherence to therapy represents a key to success.

Objective: The objective was to increase adherence to treatment through the development of educational intervention (EI) for asthma and COPD, addressed to patients and general practitioners (GPS). The educational programme includes group educational sessions and educational materials and was carried out in five Romanian hospitals. The results were assessed through Test of Adherence to Inhalers (TAl) questionnaire.

Results: Of note, 347 GPs and 435 patients were included. Seventy-six per cent of the GPs considered that the main causes of nonadherence are the disease misunderstanding, difficulty of using inhaled medication, fear of adverse effects, the patient's conviction that no medicine is useful for his illness and financial nature (20\%). Fifty-five per cent of surveyed GPs believed that their patients always or most of the time adhere to inhaled therapy but $57 \%$ of the same surveyed GPs checked the inhalation technique of their patients sometimes, rarely or never. Only 44\% of the GPs discussed with the pulmonologist about their patient's disease. Before the El, only $32 \%$ of patients had a good adherence score to therapy; this percentage increases to $57 \%$ after El. The most common reasons for nonadherence were: patient forgets to administer his inhalation medication daily (49\%), fear of adverse effects (33\%), belief that medication is useless (26\%), and fear that inhalation medication affects everyday life of the patient (24\%). Nearly half of the patients (47\%) give up medication when they feel better. Forty per cent of patients drop off inhalation treatments due to financial reasons. The most influenced behaviours as a result of the El were psychological component (85\%), fear of the adverse events (82\%) and social component (79\%). Conclusions: The non-adherence to therapy remains a real problem in asthma and COPD patients in our study group, but EI had positive effects. Extending medical education programmes for patients focused on main reasons of poor adherence, such as forgetting to take medication daily, use of inhalator devices, not understanding their disease, may significantly increase adherence to inhalation treatment.

Keywords

adherence $\cdot$ asthma $\bullet C O P D$

\section{Proiect INSPIRO - Intervenție educațională împotriva non-aderenţei la terapia inhalatorie a pacienților români cu astm și BPOC}

Rezumat

Romanian:

Introducere: În gestionarea bolilor respiratorii cronice, cum ar fi astmul și boala pulmonară obstructivă cronică (BPOC), aderența la terapie reprezintă o cheie a succesului. 
Obiectiv: Obiectivul a fost creșterea aderenței la tratament prin dezvoltarea intervenției educaționale (IE) pentru astm și BPOC, adresată pacienților și medicilor de familie. Programul educațional a inclus sesiuni educaționale de grup și materiale educaționale și s-a desfășurat în cinci spitale din România. Rezultatele au fost evaluate prin chestionarul Test de aderență la inhalatoare (TAI).

Rezultate: Au fost incluși 347 de medici de familie și 435 de pacienți. Șaizeci și șase la sută din medicii de familie au considerat că principalele cauze ale neaderării sunt neînțelegerea bolii, dificultatea utilizării medicamentelor inhalatorii, teama de efecte adverse, convingerea pacientului că niciun medicament nu este util pentru boala și latura financiară (20\%). Cincizeci și cinci la sută dintre medicii de familie chestionați cred că pacienții lor respectă întotdeauna sau de cele mai multe ori terapia inhalatorie, dar $57 \%$ din aceiași medici de familie chestionați au verificat tehnica de inhalare a pacienților lor uneori, rar sau niciodată. Doar 44\% dintre medicii de familie au discutat cu pneumologul despre boala pacientului lor. Înainte de IE, doar $32 \%$ dintre pacienți aveau un scor de aderență bun la terapie; acest procent a crescut la $57 \%$ după IE. Cele mai frecvente motive pentru neaderare au fost: pacientul uită să-și administreze zilnic medicamentele inhalatorii (49\%), teama de efectele adverse (33\%), credința că medicamentul este inutil (26\%) și teama că medicamentul inhalator afectează viața de zi cu zi a pacientului (24\%). Aproape jumătate dintre pacienți (47\%) renuntă la medicamente atunci când se simt mai bine. $40 \%$ din pacienți renunță la tratamentele inhalatorii din motive financiare. Cele mai influențate comportamente ca urmare a IE au fost componenta psihologică (85\%), frica de evenimentele adverse (82\%) și componenta socială (79\%).

Concluzii: Neaderarea la terapie rămâne o problemă reală la pacienții cu astm și BPOC din grupul nostru de studiu, dar intervenția educațională a avut efecte pozitive. Extinderea programelor de educație medicală pentru pacienți axată pe principalele motive ale aderenței slabe, cum ar fi uitarea de a lua medicamente zilnic, utilizarea dispozitivelor inhalatorii, neînțelegerea bolii lor, poate crește semnificativ respectarea tratamentului inhalator.

Cuvinte-cheie

aderare $\cdot \operatorname{astm} \cdot B P O C$

\section{Introduction}

Asthma and chronic obstructive pulmonary disease (COPD) are important healthcare problems, and it is expected that COPD will become the fourth leading cause of death worldwide by 2030 . Beside medication, the management of these diseases involves therapeutic education, psychological counselling, exercise and smoking cessation. Although in the last years there was an increase in the number of inhaled medications for asthma and COPD, their benefits depend on the patient adherence and compliance. The scientific guidelines include assessment of inhalation technique and adherence to inhaled therapy as key conditions to control respiratory diseases (1-3).

The adherence definition is the way patients take their medication as prescribed (4). There are many factors involved in the adherence, from the patient himself to healthcare system and social implication. Adherence is something more than to remember taking the treatment. It means patient's active participation and constant involvement in asthma and COPD management (5). For measuring the adherence, the most useful tools are questionnaires developed (6), and the most commonly used test is the TAl test that is used in our study $(7,8)$.

There are two types of non-adherence:

- Unconscious decrease adherence (with no intention). It is related to low communication between patient and physician, low execution, financial barriers, decreased prospective memory. It depends on patient's ability and resources, includes practical barriers for adherence and is easier to remediate with patient education.
- Conscious non-adherence (with intention) related to patient's beliefs and motivation, with perception barriers. In this case, the patients know what they have to do but they are not willing to do what the doctor says because the prescribed treatment does not make sense or they have concerns for therapy. It is more complex and often needs a multidisciplinary approach, focused on changing behaviours with psychotherapeutic interventions such as motivational interviewing, coaching and psychological counselling (9).

\section{Material and method}

\section{Project description}

The INSPIRO project was a pilot educational programme, initiated in 2017 by the Romanian Society of Pneumology, having as partner the National Society of Family Medicine, whose purpose was an educational intervention (EI) against non-adherence to inhalation treatment for Romanian patients with asthma and COPD.

The objective of this study was to increase adherence to treatment through the development of El programme focused on two components: medical education for asthma and COPD patients and medical education related to asthma pathology and COPD, addressed to the general practitioners (GPs), one of the most important actors in the management of these chronic conditions. 
The El programme included educational group sessions and educational materials addressed to both categories of project beneficiaries. Printed educational materials (practical guidelines for asthma and COPD) have been developed for patients together with an educational digital platform to make access to medical information easier. The teams that provided the El consisted in eight physicians per location: seven pulmonologists and one GP.

This project was carried out in five Romanian university cities: Bucharest, Cluj Napoca, Craiova, Timişoara and Constanţa. In each of the university cities involved, 5 sessions of medical education for GP and 5 medical education sessions for patients with asthma and COPD were held, each session having 15-20 participants. Educational sessions were conducted in pulmonology hospitals designated: Bucharest 'Marius Nasta' Institute of Pneumophysiology, Cluj Napoca - 'Leon Daniello' Pneumology Hospital, Constanta Pneumology Hospital, Craiova - 'Victor Babeş' Hospital for Pneumophysiology and Infectious Diseases, Timisoara 'Victor Babeş' Clinical Hospital of Infectious Diseases and Pneumophysiology.

A total of 35 pneumologists were involved in patient's educational sessions. For the educational sessions addressed to GPs, a number of five GPs were also co-opted, who, together with respiratory physicians, participated in the medical education sessions.

The meeting agenda included updates of GINA and GOLD guidelines, difficulties and solution for adherence, GP_ pulmonologist cooperation, patients' profile and the modalities to deal with different types of patients. Medical education courses for GPs have had a theoretical part in which the latest facts about asthma management and COPD have been communicated, part of a practical workshop where the psychological profile of the patient with asthma and COPD has been approached and how to use this profile to improve adherence to inhaled treatment.

Agenda of patient education sessions also included information on disease and how to use inhaled devices (practical demonstrations with demonstration devices). The programme comprises educational sessions, digital platform (website) and printed materials distributed to patients during educational sessions. The printed education materials were practical asthma/COPD guidelines developed for patients' use.

The educational session for COPD patients includes the following as subjects of discussion: definition and impact of the disease, severity in lung function impairment (GOLD), main risk factors for COPD such as smoking, exposure to other contaminants, COPD in younger people, spirometry (what is it and how it is done), COPD symptoms (importance of recognising and going to physician), COPD treatment such as importance of daily administration, adherence to bronchodilator treatment, COPD exacerbations such as symptoms, severity, emergency visits and hospitalisations. The subjects of educational sessions for asthma patients included asthma definition, allergens, asthma severity, symptoms, asthma diagnostic, asthma impact on daily life (effort tolerance, work absenteeism, stress, working-related asthma), pregnancy and asthma.

In this educational programme were included 435 patients and 347 GPs. To evaluate the effectiveness of El, questionnaires were applied both to GPs and patients. For GPs, two questionnaires were applied: an assessment of the educational course quality and a questionnaire developed to determine the GP's perception of how their patients with asthma and COPD manage their illness and GP's approach to current medical practice for asthma and COPD.

For patients, to measure the effectiveness of medical education intervention, the Test of Adherence to Inhalers (TAI) questionnaire was used. TAl is a 12-item reliable questionnaire used to identify non-adherence and barriers related to inhalers in asthma and COPD $(4,8)$. This test helps to identify patients with low adherence and to determine adhesion: good, intermediate or reduced. A score of 50 points translates as good adherence; the score between 46 and 49 points shows an intermediate adherence and a score of $\leq 45$ points reveals low adherence to inhalation therapy.

This TAI was initially applied to all patients who participated in the educational sessions, and at 3 months the same test was reapplied through telephone to patients to see if there was any change in adherence to inhaled treatment after El.

Non-adherence was defined by a TAI score $<50$ points (nonadhesion and intermediate adherence), while adherence to treatment was defined by a 50-point TAl score.

To calculate the intervention on education (IE), the following formula was used:

Change from baseline - per cent (\%)

Formula \% change $($ vs. initial $)=$ Final value/initial value -1

\section{Results}

\section{El for GPs}

In total, 347 GPs completed the evaluation questionnaires. A total of 25 educational courses were performed in 5 university hospitals with 5 courses per hospital.

When the quality of the course was assessed, $>90 \%$ of the answers were positives. GPs considered that the content and speakers quality was high (98\%) and the educational intake for asthma and COPD was increased (90-91\%). Ninety-one per cent of them believed that these interventions will change their clinical practice. 
Another part of the questionnaire regarded the GP's perception of how patients with asthma and COPD manage their illness and GP's approach to current medical practice for asthma and COPD. From the analysis of the answers, $76 \%$ of the GPs considered that the main causes of nonadherence are misunderstanding of the disease, difficulty in using inhaled medication, fear of adverse effects, patient's conviction that no medicine is useful for his illness, while only $20 \%$ of the non-adherence motivation is of a financial nature (Figure 1).

Fifty-five per cent of surveyed GPs believed that their patients always or most of the time adhere to inhaled therapy, and $41 \%$ of them considered their patients to be inadequate with their medication, with respect to posology sometimes, rarely or not (Figure 2).

At the question about how often they check inhalation device with their patients, $57 \%$ of GPs answered that rarely or never check this inhalation technique, while only $43 \%$ always or mostly checked this technique (Figure 3).

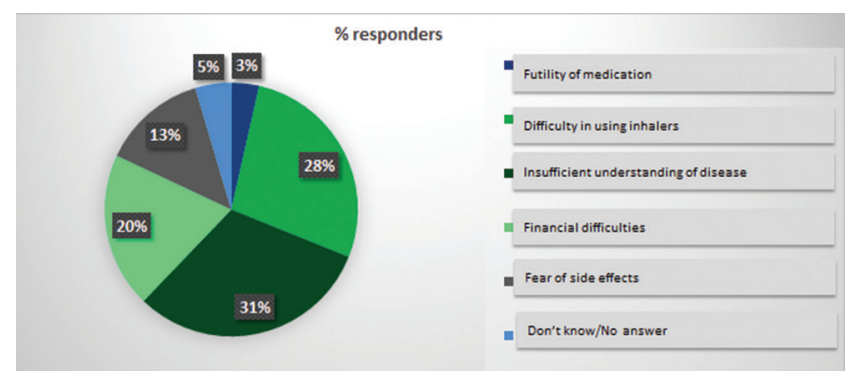

Figure 1. General practitioner's perception for non-adherence.

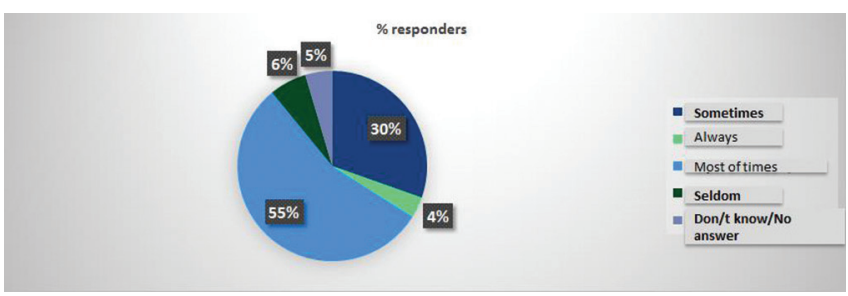

Figure 2. General practitioner's perception for adherence to inhaled therapy.

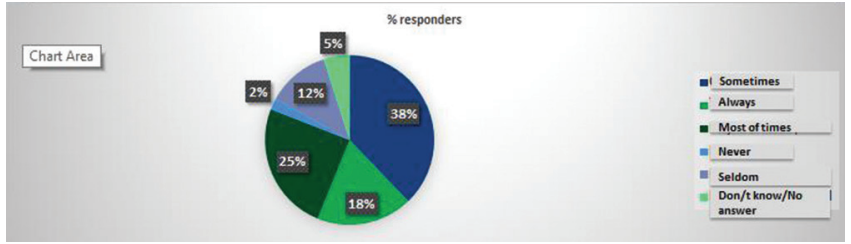

Figure 3. Checking the inhalation technique by the general practitioner.
When they were asked about how often they are referring the patients to a pulmonologist for a periodic evaluation, $86 \%$ of the GPs recommended that asthma or COPD patients to be re-evaluated by the respiratory physician (Figure 4).

Only $44 \%$ of the GPs interviewed consulted with the pulmonologist about the evolution of their patient's disease, while $56 \%$ of them consulted the respiratory specialist sometimes, rarely or even never (Figure 5).

\section{El for patients}

In total, 435 patients attended the educational sessions: 130 in Bucharest, 91 in Cluj-Napoca, 99 in Constanta, 69 in Craiova and 46 in Timisoara (Figure 6). There were 5 educational

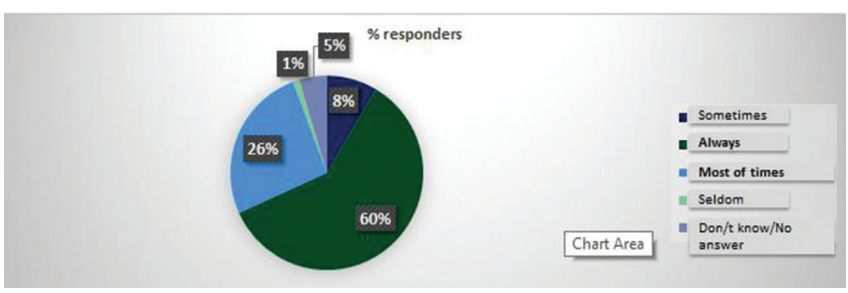

Figure 4. Referral of patients to a pulmonologist by the general practitioner.

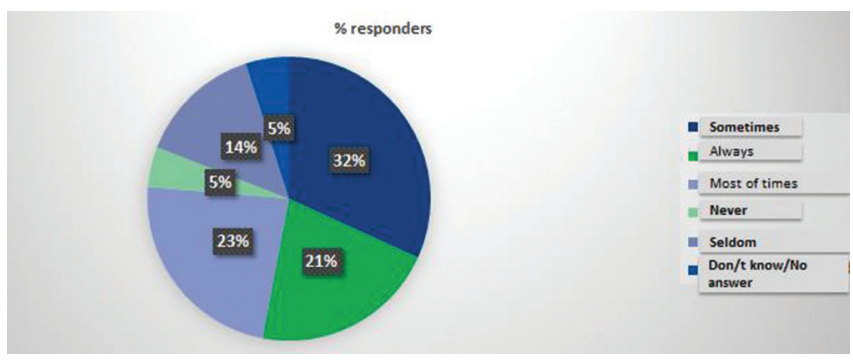

Figure 5. Consultation of a pulmonologist by the general practitioner.

\section{Distribution of patients}

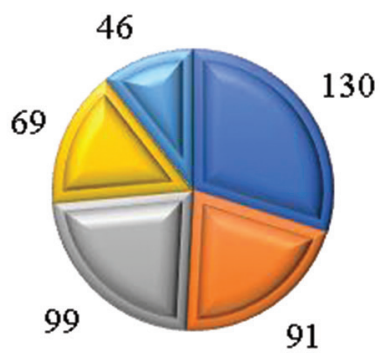

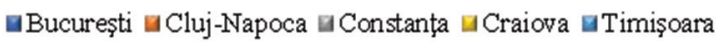

Figure 6. Distribution of patients on university Romanian centres. 


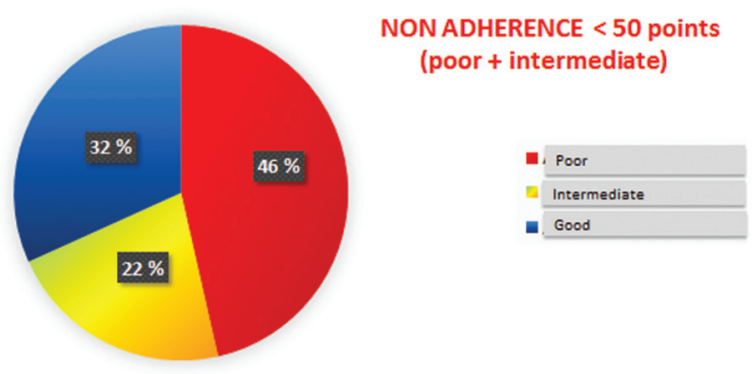

Figure 7. Adherence to inhalers in Romania.

sessions per university cities, with a total of 25 educational sessions.

When the results of TAl test before El were assessed, the results showed that $68 \%$ of patients surveyed (prior to educational sessions) are non-adherent to inhalation treatments (poor or intermediate adherence degree with TAl score $<50$ points) with only $32 \%$ of them having good adherence to treatment (Figure 7).

When the adherence was analysed geographically, the highest adherence to inhaled therapy is Craiova (49\%), while Timisoara and Cluj Napoca are the lowest adherence areas in this group ( $24 \%$ and $25 \%$, respectively).

The most common reason for non-adherence was that $49 \%$ of patients forget to administer their daily inhalation medication. Nearly half of the patients $(47 \%)$ give up medication when they feel better. Insufficient understanding of the disease or lack of accurate information about the disease is responsible for other reasons of non-adherence such as fear of adverse effects $-33 \%$, belief that medication is useless $-26 \%$ and fear that inhalation medication affects everyday life of the patient $-24 \%$.

If GPs felt that financial motivation was responsible for $20 \%$ of cases of non-adherence to inhaled treatment, patients identified financial motivation as being responsible for giving up $40 \%$ of the inhaled treatment.

Forty per cent of patients questioned do not follow the physician's recommendations on the number of doses or frequency of inhaled therapy, using fewer doses than recommended.

\section{Outcomes after El}

Patients were contacted through telephone after at least 3 months of medical education courses to respond to TAI questionnaire. Contacts presented valid telephone numbers in the initial questionnaires completed at the educational sessions. A total of 255 patients participated in this part of our study.

As a result of the El through the educational sessions with the patients, $57 \%$ of the patients who were interviewed after the interventional education had a good adherence score,
Table 1. Patient's adherence before and after interventional education

\begin{tabular}{lcc}
\hline \multicolumn{3}{c}{ Results of TAI Romania post-intervention } \\
\hline Romania & No. of patients & \% of patients \\
\hline Low grip & 48 & 19 \\
Intermediate adhesion & 62 & 24 \\
Good grip & 145 & 57 \\
\hline Total Romania & 255 & \\
\hline
\end{tabular}

\% pacpreIE $\quad \%$ pac post IE

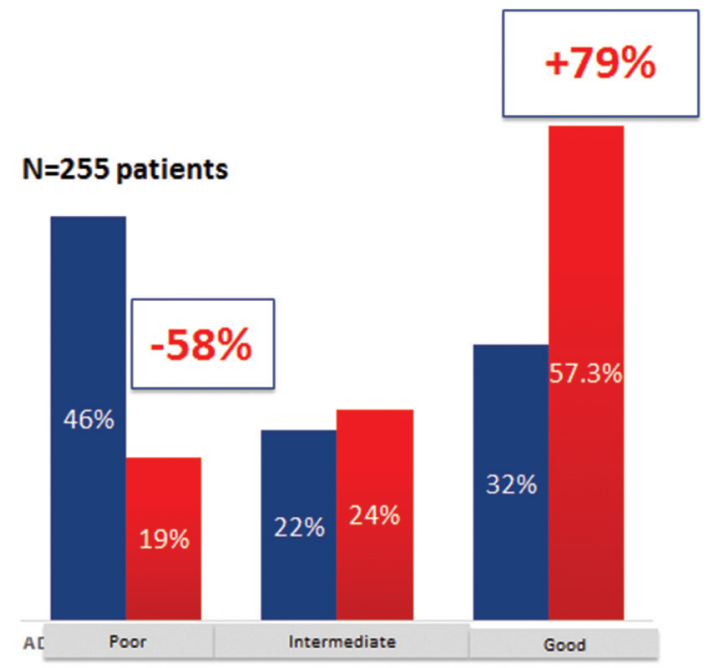

Figure 8. Changes in adherence to inhaled post-intervention treatment.

while $43 \%$ had low and intermediate adherence scores (Table 1).

Compared with the baseline, $<58 \%$ patients with reduced adherence and $>79 \%$ patients with good adherence to inhaled therapies were found (Figure 8).

After the educational sessions, there was a positive change in non-adherence compared with baseline. As a result of the $\mathrm{El}$, the most influenced behaviours were the psychological component $(-85 \%)$, fear of the adverse events $(-82 \%)$ and the social component (-79\%) (Figure 9).

Influenced behaviours in a smaller but impressive measure of El were no utility of treatment $(-77 \%)$, fewer doses than recommended $(-73 \%)$, financial motivation $(-50 \%)$ and insufficient understanding of the chronic character of the disease: $<59 \%$ patients who forget to administer their inhalation medication daily and $<53 \%$ patients who give up their inhaled medication when they feel better (Figure 10a and b).

The analysis of TAl questionnaire, pre- and post-intervention, revealed the following results:

- Eighty per cent of patients received their inhaled medication every day of the last week, compared with $51 \%$ prior to 
educational intervention (Figure 11). Conversely, if $43 \%$ of patients discontinued inhaled medication over the last 7 days before IE, only $19 \%$ were in the same situation after IE.

- Only $20 \%$ of patients stop medication because they forget to administer it, compared with $49 \%$ before the educational sessions.

- Only $22 \%$ of patients stop inhaled medication when they feel better compared with $47 \%$ prior to educational intervention (Figure 11).

- Only $8 \%$ of patients stop inhaled medication when they go on vacation or weekend, compared with $36 \%$ before IE.

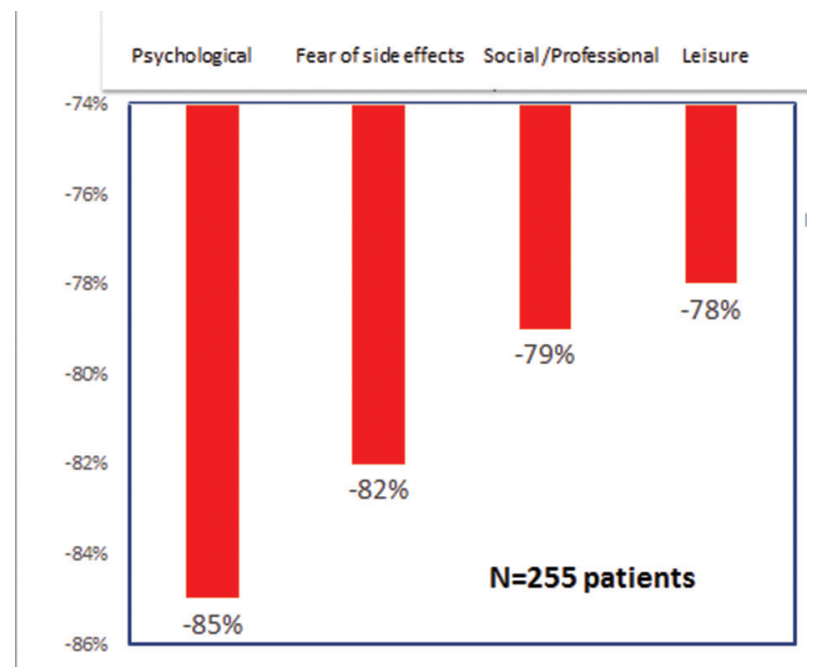

Figure 9. Results of the behaviour changes after intervention on education.
- After educational intervention, only $5 \%$ of patients stop inhaled medication when they experience nervousness, annoyance, sadness, compared with $33 \%$ of patients who were in this situation before IE.

- After educational intervention, only $6 \%$ of patients give up inhaled medication because of fear of side effects, compared with $33 \%$ before IE.

- After educational intervention, only $6 \%$ of patients give up inhaled medication because they consider it unnecessary compared with $26 \%$ before IE.

- After educational intervention, only $11 \%$ of patients take fewer doses from the inhaled medication recommended by the physician, compared with $40 \%$ before IE (Figure 11).

- After educational intervention, only $5 \%$ of patients give up inhaled medication because it would affect their daily or professional life, compared with $24 \%$ before IE.

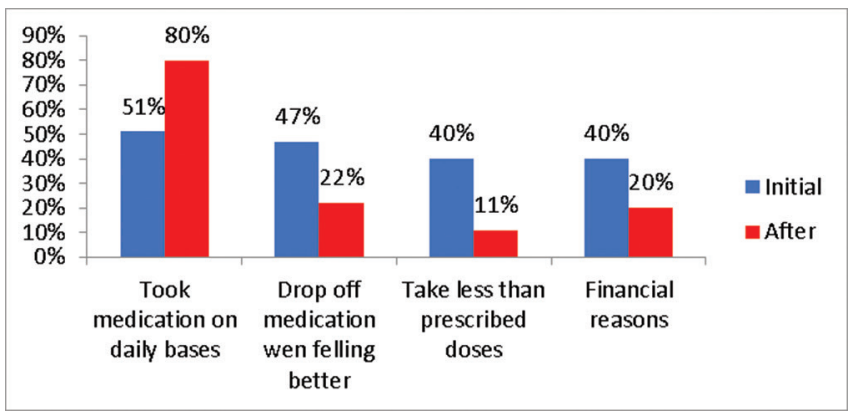

Figure 11. Impact on adherence to inhalation treatment of educational interventions for chronic obstructive pulmonary disease and asthma patients.
A

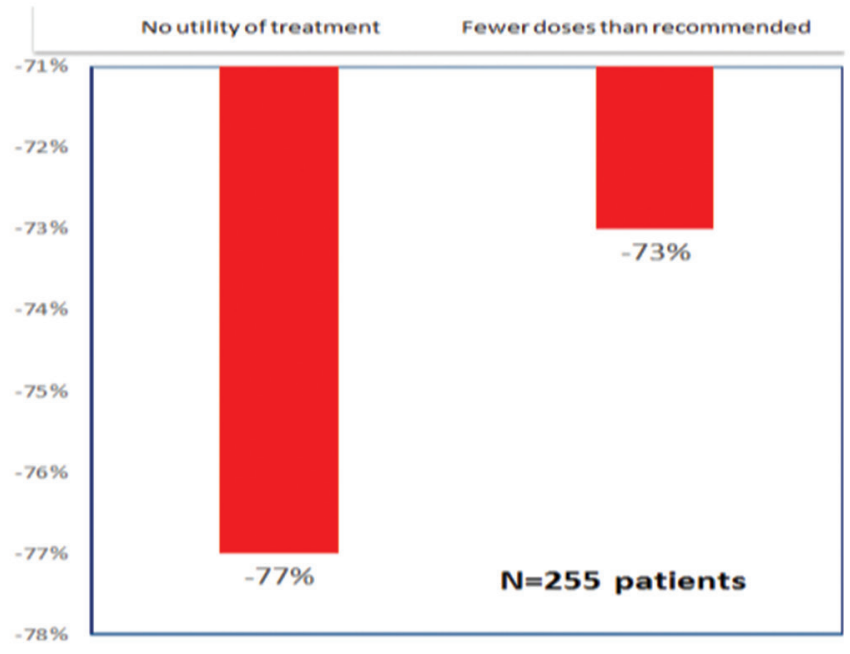

B

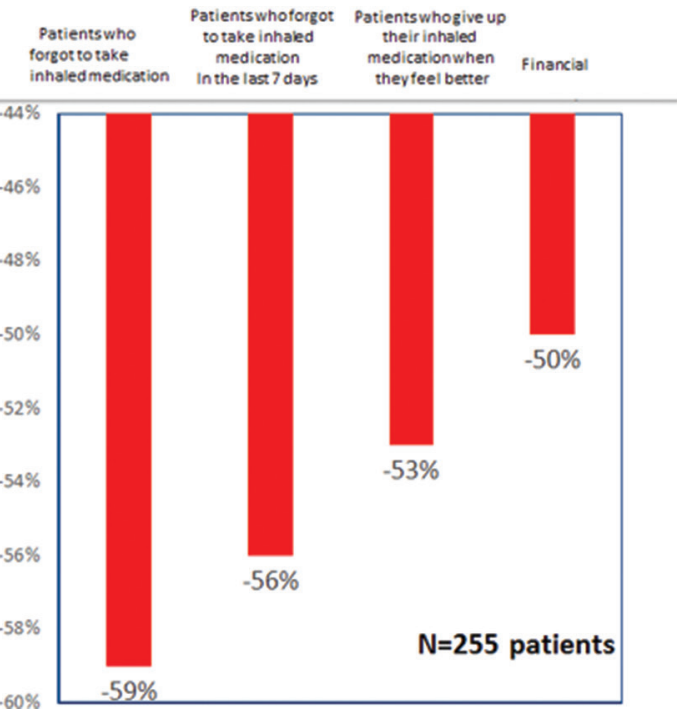

Figure 10. ( $a$ and $b$ ) Results of other behaviour changes after intervention on education. 
- After educational intervention, a reduction of almost $50 \%$ in the number of patients who give up inhaled medication for financial reasons was noticed (Figure 11).

\section{Discussions}

This project was the first Romanian concomitant analysis of adherence in asthma and COPD from two sides involved: patients and general physicians. It also studied the role of educational interventions in decreasing non-adherence among the COPD and asthma patients.

The results of our project showed that prior to educational sessions $68 \%$ of patients surveyed are non-adherent to inhaled treatments, with only $32 \%$ of them having good adhesion score. This percentage is similar with the other data reported (6) which show that $40-60 \%$ of COPD patients adhere to the prescribed therapy. However, our educational intervention managed to raise the percentage of good adherence to $57 \%$. Another study performed in stable COPD founded that $31.3 \%$ of patients were poorly adherent and $16.7 \%$ of patients were non-adherent to the inhaled therapy (10).

In our patient's case, the most common reason for nonadherence was that $49 \%$ of patients forget to administer their daily inhalation medication. Actually, in the last week before attending the educational sessions, only $51 \%$ of our patients have received inhaled medication daily. Nearly half of the patients (47\%) give up medication when they feel better, $33 \%$ have fear of adverse effects, $26 \%$ believe that medication is useless. This indicates an insufficient understanding of the chronic nature of the disease. To overcome these barriers, these subjects must be discussed one by one with every patient.

After participating in the interventional education sessions, the percentage of poor adherence decreased significantly from $46 \%$ to $22 \%$. This positive result may be the consequence of better understanding of the disease and the necessity of longtime treatment.

Another interesting finding of our study was that while GPs thought that financial motivation is responsible for $20 \%$ of cases of non-adherence to inhaled treatment, $40 \%$ of patients identified financial motivation as being responsible for giving up the inhaled therapy. This finding may be due to the fact that COPD is a disease that appears at an old age and many patients are pensioners with low incomes. Clearly, financial reasons have an overwhelming role in giving up inhalation treatments.

When TAl questionnaire was applied at the beginning of the study, it showed that $44 \%$ of patients use fewer doses of inhaled medication recommended by a physician, and this percentage dropped to $11 \%$ after IE. The explications for using fewer doses than prescribed may be due to financial reasons (patients think that the inhaler will last longer), embarrassment of using inhaler in front of service colleagues or family and forgetfulness. It should not be forgotten that these patients, especially those with COPD, often have associated comorbidities and use a large number of other drugs besides inhalation therapy.

There are also three types of non-adherence to therapy: underuse, overuse and improper use. Underuse is a decrease of recommended daily dose of treatment $(11,12)$. Improper use is the case when a drug is ineffective, not indicated or unnecessary duplication (13).

While in asthma the main form of adherence problem is due to overuse of short-acting beta agonists, in COPD the most common type of non-adherence is underuse $(12,14)$. Improper use is also found in COPD patients who are older, have comorbidities and must take two or more medications (13). Other factors associated with unnecessary drug use include low income, lack of patient's health belief and older age $(15,16)$.

Aspecial situation is related to exacerbation, when the patients feel the needs to temporarily increase the medication, leading to overuse. A part of them, however, as they feel better, reduce the dose of treatment which leads to underuse. A medication may be inappropriate if there are lack of effectiveness and lack of indication $(13,15)$. Psychological status and socioeconomics issues are also associated with risk of poor adherence. Depressed patients are threefold higher at risk for non-adherence $(6,17)$.

Finding effective methods to combat non-adherence is a challenge, involving patients' good knowledge of the disease, confidence in prescribed therapy and a good patient-physician relation. The fact that must be taken into account is that COPD patients often need to make important lifestyle changes regarding other faces of the disease, for example, stop smoking, oxygen therapy and exercise training.

In our study, the interventional education lead to a huge positive surprise, with $<58 \%$ patients with poor adherence and $>79 \%$ patients with good adherence. The most influenced behaviours as a result of the educational intervention were the psychological component $(-85 \%)$, the fear of the adverse events $(-82 \%)$ and the social component $(-79 \%)$. Influenced behaviours in a smaller but impressive measure of educational intervention were financial motivation $(-50 \%)$ and insufficient understanding of the chronic character of the disease: $<59 \%$ patients who forget to administer their inhalation medication daily and $<53 \%$ patients who give up their inhalation medication when they feel better.

When the GP point of view was assessed, they believed that $75 \%$ of patients' non-adherence is related to disease misunderstanding, difficulty in using inhalers, fear of side effects, futility of medication, financial reasons (20\%). They 
also thought that $41 \%$ patients take their medication as prescribed.

When we are looking at GPs management of asthma and COPD in real life, we have contradictory answers. Eighty-six per cent GPs refer asthma/COPD patients to a pulmonologist for periodic evaluation but $51 \%$ GPs never/rarely consult a pulmonologist for the management of their asthma/COPD patients. In fact, it was shown in the study conducted by Foster in primary care settings that although $55 \%$ of primary care physicians were aware of major COPD guidelines, only $25 \%$ used them to prescribe therapy $(6,18)$. They used mostly spirometry as parameter to guide treatment. Other studies involving GPs survey showed that even the GPs were aware of non-adherence in their asthma and COPD patients, and they underestimated the real prevalence and its consequences (19). Regarding GPs perception for patients' attitude on asthma/ COPD, there are also contradictory answers: 59\% of GPs think that patients are taking inhaled medication correctly most of time, but $57 \%$ of the GPs check inhalation technique rarely or never. The technique by which inhaled therapy is administrated is very important. Restrepo showed that only 1 out of 10 patients who use a metered dose inhaler follows all steps correctly (6).

However, overall perception of the GPs about our project was positive: the quality of educational interventions was high $(>90 \%)$ and those interventions will change their clinical practice (91\%).

Although asthma and COPD are chronic disease that cannot be cured, there is a constant interest in establishing guidelines for therapy, with positive results on symptoms, exacerbations and improved quality of life. But beside the idealistic approach is the individual patient with his own beliefs and problems, and patient-related determinants of non-adherence are not completely understood.

Asthma and COPD management may be suboptimal either when physicians do not prescribe appropriate therapies, or when patients fail to adhere to prescribed inhaled therapy. Literature studies showed that COPD patients are less adherent to therapy than asthma patients $(6,20,21)$. Up to $60 \%$ of COPD patients do not adhere to prescribed therapy and up to $85 \%$ of patients use their inhaler ineffectively $(6,21-$ 23). A study that evaluated the patient satisfaction with the inhalers showed that there is an association between the adherence, control disease and patient satisfaction in asthma patients (24).

The measurement of non-adherence is also challenging, and the solution is to use a combination of instruments. For example, a Spanish cross-sectional, observational multicentre study in asthma or COPD patients evaluated the adherence using TAl questionnaire together with pharmacy refill records. The non-adherence percentage was $58.1 \%$ for TAI and $28.6 \%$ for pharmacy refill records, versus $64.6 \%$ for the combined data, showing that a combined test for adherence identifies a higher number of patients than a single test (25).

\section{Conclusions}

Asthma and COPD are chronic diseases and their management is full of provocation. In our study, prior to educational intervention, only $32 \%$ of patients had good adherence to inhaled therapy. However, this percentage increased to $57 \%$ after IE. Medical education leads to better understanding of the chronic nature of these illnesses and has also led to a reduction in the percentage of patients who give up inhaled medication from $40 \%$ before intervention to 20\% after intervention. Educational intervention in the form of educational sessions has demonstrated its importance, whether it refers to patients or GPs.

As far as the general physicians are concerned, the analysis of the questionnaires has shown that there is a need for a change in the collaboration of pulmonologist-GP with a focus on practical aspects and clinical cases to improve the joint management of asthma and COPD cases. Closer collaboration can lead to increased adherence to treatment for asthma and COPD patients, as it allows for more careful monitoring of the therapeutic effectiveness and the correct use of inhaled devices.

Educational intervention is essential for patients, acting on the main causes of non-adherence: patients who forget to administer medication, the correct use of inhaled devices and patients with poor understanding of the chronic nature of their disease. Although there are many people around, only the patient ultimately decides whether or not to take his medication. That is why we believe that extending medical education programmes for patients, specifically addressing the causes of non-adherence identified in the INSPIRO project, can greatly increase adherence to inhaled treatments.

\section{Ethical approval}

The present study received ethical approval from the Council of Romanian Society of Pneumology.

Inform consent was obtained from the patients to participate in the study and write the article.

\section{References}

1. The Global Initiative for Asthma (GINA) 2019 Edition. Available from: https://ginasthma.org. 
2. The Global Initiative for Chronic Obstructive Lung Disease (GOLD) 2019 Edition. Available from: https://goldcopd.org.

3. Ulmeanu R, Fildan AP, Oancea C, Mihaltan FD. Recomandari de diagnostic si tratament in bronhopneumopatia cronica obstructiva. Editura Medicala, Bucuresti 2019.

4. Vrijens B, de Geest S, Hughes DA, Przemyslaw K, Demonceau $\mathrm{J}$, Ruppar T, et al. A new taxonomy for describing and defining adherence to medications. British Journal of Clinical Pharmacology. 2012;73(5): 691-705.

5. Mihaltan F, Ulmeanu R. Algoritm de terapie in pneumologie. Editura Medicala, 2016.

6. Restrepo RD, Alvarez MT, Wittnebel LD, Sorenson H, Wettstein $\mathrm{R}$, Vines $\mathrm{DL}$, et al. Medication adherence issues in patients treated for COPD. International Journal of Chronic Obstructive Pulmonary Disease. 2008;3(3): 371-384.

7. TAI. Available from: www.taitest.com.

8. Plaza V, Fernández-Rodríguez $\mathrm{C}$, Melero $\mathrm{C}$. Validation of the 'Test of the Adherence to Inhalers' (TAI) for Asthma and COPD Patients. Journal of Aerosol Medicine and Pulmonary Drug Delivery. 2016;29(2): 142-152.

9. George M. Adherence in Asthma and COPD: New strategies for an old problem. Respiratory Care. 2018;63(6): 818-831.

10. Duarte-de-Araújo A, Teixeira P, Hespanhol V, Correia-deSousa J. COPD: understanding patients' adherence to inhaled medications. International Journal of Chronic Obstructive Pulmonary Disease. 2018;13: 2767-2773.

11. Levens Lipton H, Bero LA, Bird JA, McPhee SJ. Undermedication among geriatric outpatients: results of a randomized controlled trial. Annual Review of Gerontology and Geriatrics. 1992;12: 95-107.

12. Harrow BS, Strom BL, Gans JA. Impact of pharmaceutical underutilization: a study of insurance drug claims data. Journal of the American Pharmaceutical Association (Wash). 1997;NS37: 511-516.

13. Steinman MA, Landefeld CS, Rosenthal GE, Berthenthal D, Sen S, Kaboli PJ. Polypharmacy and prescribing quality in older people. Journal of the American Geriatrics Society. 2006;54: 1516-1523.

14. George J, Kong DC, Thoman R, Stewart K. Factors associated with medication nonadherence in patients with COPD. Chest. 2005;128: 3198-3204.
15. Rossi MI, Young A, Maher R. Polypharmacy and health beliefs in older outpatients. The American Journal of Geriatric Pharmacotherapy. 2007;5(4): 317-323.

16. Insel K, Morrow D, Brewer B, Figueredo A. Executive function, working memory, and medication adherence among older adults. The Journals of Gerontology: Series B. 2006;61(2), P102-P107,

17. DiMatteo MR, Haskard KB, Williams SL. Health beliefs, disease severity, and patient adherence: a meta-analysis. Medical Care. 2007;45(6): 521-528.

18. Foster JA, Yawn BP, Maziar A, Jenkins T, Rennard SI, Casebeer L. Enhancing COPD management in primary care settings. Medscape General Medicine. 2007;9(3): 24.

19. Kardas $P$, Lewek $P$, Strzondała M. Adherence to treatment in asthma and COPD patients in their doctors' assessment. Pneumonologia i alergologia polsk. 2015;83(6): 436-444. doi:10.5603/PiAP.2015.0072.

20. James PNE, Anderson JB, Prior JG, White JP, Henry JA, Cochrane GM. Patterns of drug taking in patients with chronic airflow obstruction. Postgraduate Medical Journal. 1985;61: 7-10.

21. Haupt D, Krigsman K, Nilsson JL. Medication persistence among patients with asthma/COPD drugs. Pharmacy World \& Science. 2008; 5 Feb [Epub ahead of print].

22. Bosley CM, Parry DT, Cochrane GM. Patient compliance with inhaled medication. Does combining beta agonists with corticosteroids improve compliance? European Respiratory Journal. 1994; 7: 504-509.

23. Krigsman K, Lars JG, Ring L. Refill adherence for patients with asthma and COPD: comparison of a pharmacy record database with manually collected repeat prescriptions. Pharmacoepidemiology and Drug Safety. 2007;16: 441-448.

24. Donaire JG, Pérez DD, Hernández C, Cabestre R. Study to evaluate satisfaction with the inhalation device used by patients with asthma or chronic obstructive pulmonary disease and the association with adherence and disease control. Journal of Aerosol Medicine and Pulmonary Drug Delivery. 2020;33(3): 153-160. doi: 10.1089/jamp.2019.1541

25. Plaza V, Giner J, Curto E, Alonso Ortiz MB, Orue MI, Vega JM, et al. Assessing adherence by combining the test of adherence to inhalers with pharmacy refill records. Journal of Investigational Allergology and Clinical Immunology. 2019 Oct 10. doi: 10.18176/jiaci.0461 


\section{Supplementary materials}

The team of the INSPIRO project

National coordinator of INSPIRO project

Ruxandra Ulmeanu - Romanian Society of Pneumology

Coordinators from National Society of Family Medicine

Rodica Tanasescu

Catalina Panaitescu

\section{BUCHAREST}

Regional coordinator: Florin Mihălțan

Pulmonologists: Ramona Nedelcu, Ana Maria Zaharie, Andreea Vlădău, Claudia Toma, Dragoş Zaharia, Ştefan Dumitrache Rujinski

General practitioner: Adela lancu

\section{CLUJ NAPOCA}

Regional coordinator: Daniela Boldeanu

Pulmonologists: Domokos Hancu Bianca, Leşan Andrei, Motoc Nicoleta, Râjnoveanu Ruxandra, Arieşanu Nicoleta, Roşca Loredana

General practitioner: Anca Bălan

\section{CRAIOVA}

Regional coordinator: Floarea Mimi Niţu

Pulmonologists: Cristina Călăraşu, lleana Bazavan, Mihai Olteanu, Ramona Cioboată, Teodora Schwarz, Victor lonel Grecu General practitioner: Gabriela Comişel

\section{CONSTANTA}

Regional Coordinator: Ariadna Petronela Fildan

Pulmonologists: Doina Pîrîu, Doina Tofolean, Elena Danteş, Mihaela Damian, Mihaela Trenchea, Oana Arghir General practitioner: Sergiu Chirilă

\section{TIMISOARA}

Regional coordinator: Cristian Oancea

Pulmonologists: Bertici Nicoleta, Daniel Trailă, Marc Monica, Ovidiu Fira Mladinescu

Tudorache Emanuela, Tudorache Voicu

General practitioner: Claudia Iftode 